Engineering, Technology and Techniques

Vol.60: e17160101, January-December 2017 http://dx.doi.org/10.1590/1678-4324-2017160101 ISSN 1678-4324 Online Edition

AN INTERNATIONAL JOURNAL

\title{
Biosorption of anionic textile dyes from aqueous solution by yeast slurry from brewery
}

\author{
Ketinny Camargo de Castro ${ }^{1}$, Aline Silva Cossolin ${ }^{1}$, Hélen Cristina Oliveira dos Reis ${ }^{1}$, \\ Eduardo Beraldo de Morais ${ }^{1 *}$. \\ ${ }^{1}$ Universidade Federal de Mato Grosso - Departamento de Engenharia Sanitária e Ambiental, Cuiaba, Mato \\ Grosso, Brasil.
}

\begin{abstract}
This study investigated the biosorption of the anionic textile dyes: Reactive Red 239 (RR239), Reactive Black B $(R B B)$ and Direct Blue 85 (DB85) according to pH, biomass dosage, contact time and dye concentration onto waste beer yeast slurry. The kinetics and isotherm of the removal of dyes were also studied. The equilibrium of biosorption reaction was reached after $30 \mathrm{~min}$ for the reactive dyes and after $60 \mathrm{~min}$ for the direct dye. Optimum decolorization was observed at $\mathrm{pH} 2$ and $0.63 \mathrm{~g} / \mathrm{L}$ of biomass dosage. The kinetic data of the three dyes were better described by the pseudo second-order model. The adsorption process followed the Langmuir isotherm model and the biosorption capacity being estimated to be 152.9, 162.7 and $139.2 \mathrm{mg} / \mathrm{g}$ for RR239, RBB and DB85, respectively. Our findings indicated that the waste beer yeast slurry was an attractive low-cost biosorbent for the removal of anionic textile dyes from aqueous solution.
\end{abstract}

Key words: bioadsorptive decolorization, waste beer yeast slurry, biosorption kinetics, biosorption isotherms.

\footnotetext{
*Author for correspondence: beraldo_morais@yahoo.com.br
} 


\section{INTRODUCTION}

Textile industries consume large amounts of water, chemicals and dyes. Approximately $10-15 \%$ of dyes applied in the dyeing process are discharged with wastewater causing environmental pollution (Al-Amarani et al., 2014). Reduction of light penetration, which is essential for photosynthesis, difficult oxygen transfer, and alteration of aesthetic characteristics are some impacts from the disposal of colored waste into aquatic ecosystems (Juang et al., 2008; Tunç et al., 2009; Saratale et al., 2011). In addition, many textile dyes and their metabolites are toxic, mutagenic and carcinogenic to some aquatic organisms and human beings (Banat et al., 1997; Gill et al., 2002).

Various physical and chemical methods such as chemical coagulation, precipitation, ultrafiltration, color irradiation, ozonation, and advanced oxidation have been used to treat textile wastewater. These methods, however, possess inherent limitations such as high cost, intensive energy requirements and formation of toxic by-products (secondary pollution) (Chen et al., 2003; Kumari and Abraham, 2007; Akar et al., 2009; Verma et al., 2012).

Adsorption is an efficient and economic process to remove pollutants from the wastewater. Activated carbon is the principal material used in the adsorption process but its high cost and problem with regeneration limit its application on a large scale (Malik, 2004; Chevalier et al., 2007; Wang and Guo, 2011). On the order hand, adsorption by biological material provides an alternative way for the bioadsorptive decolorization. In the past few years, extensive studies have been undertaken to decolorize aqueous solution and textile wastewater using biomass from apple pomace and wheat straw (Robinson et al., 2002), cotton plant (Tunç et al., 2009), pine leaves (Deniz and Karaman, 2011), fungi and yeast (Iscen et al., 2007; Kumari and Abraham 2007; Kalaiarasi et al. 2012; Wang and Guo, 2011), bacteria (Han and Yun, 2007), algae (Daneshvar et al., 2012, Khataee et al., 2013), sugarcane bagasse (Ferreira et al., 2015; Raymundo, et al. 2010; Yu et al., 2015) and cashew nut shell (Subramaniam and Ponnusamy, 2015). Generally, these biosorbents are abundant in nature, or are by-products or waste from the industry, having little or no economic value, and require minimal or no processing (Tunç et al., 2009).

Beer production is an important economic activity in many countries. Consequently, waste beer yeast is produced in large quantities at low-cost, which makes it an interesting target for the examination of its dye biosorption potential. This waste has already been used efficiently to remove heavy metals like cooper, lead, chromium, nickel, zinc, cadmium, manganese, aluminum, and uranium (Riordam et al., 1997; Kim et al., 2005; Han et al., 2006; Parvathi and Nagendran, 2008, Machado et al., 2010; Ramírez-Paredes et al., 2011). Recently, researches demonstrated the potential of waste beer yeast for biodecolorization of Acid Orange 7 (Wu et al., 2011) and Reactive Blue 49 (Wang and Guo, 2011). However, bioadsorption studies on textile dyes using waste beer yeast may be unsatisfactory, mainly when it is found a high chemical diversity of dyes and application of waste beer yeast in form of slurry.

The aim of this study was to investigate the potential usability of waste beer yeast slurry (WBYS) for the decolorization of aqueous solutions containing the anionic textile dyes: C.I Reactive Red 239, C.I. Reactive Black B and C.I. Direct Blue 85. Effects of initial $\mathrm{pH}$, contact time, dye and biosorbent concentration were evaluated. In order to obtain a better understanding of the biosorption mechanisms for future applications in real scale, the kinetics and isotherm of removal of dyes were also studied. 


\section{MATERIAL AND METHODS}

\section{Dyes}

Anionic textile dyes, i.e., C.I Reactive Red 239, C.I. Reactive Black B and C.I. Direct Blue85 were purchased from Têxtil São João (São João da Boa Vista, SP, Brazil), and used as received, without further purification. The chemical structures of the dyes are shown in Table 1. Stock solutions of the dyes were prepared by dissolving the powdered dyestuff in distilled water (1.0-5.0 g/L). The maximum absorbance $\left(\lambda_{\max }\right)$ of the individual dyes was determined by a UV-Visible spectrophotometer (Hach DR6000).

Table 1 - Structure and characteristics of the anionic textile dyes.

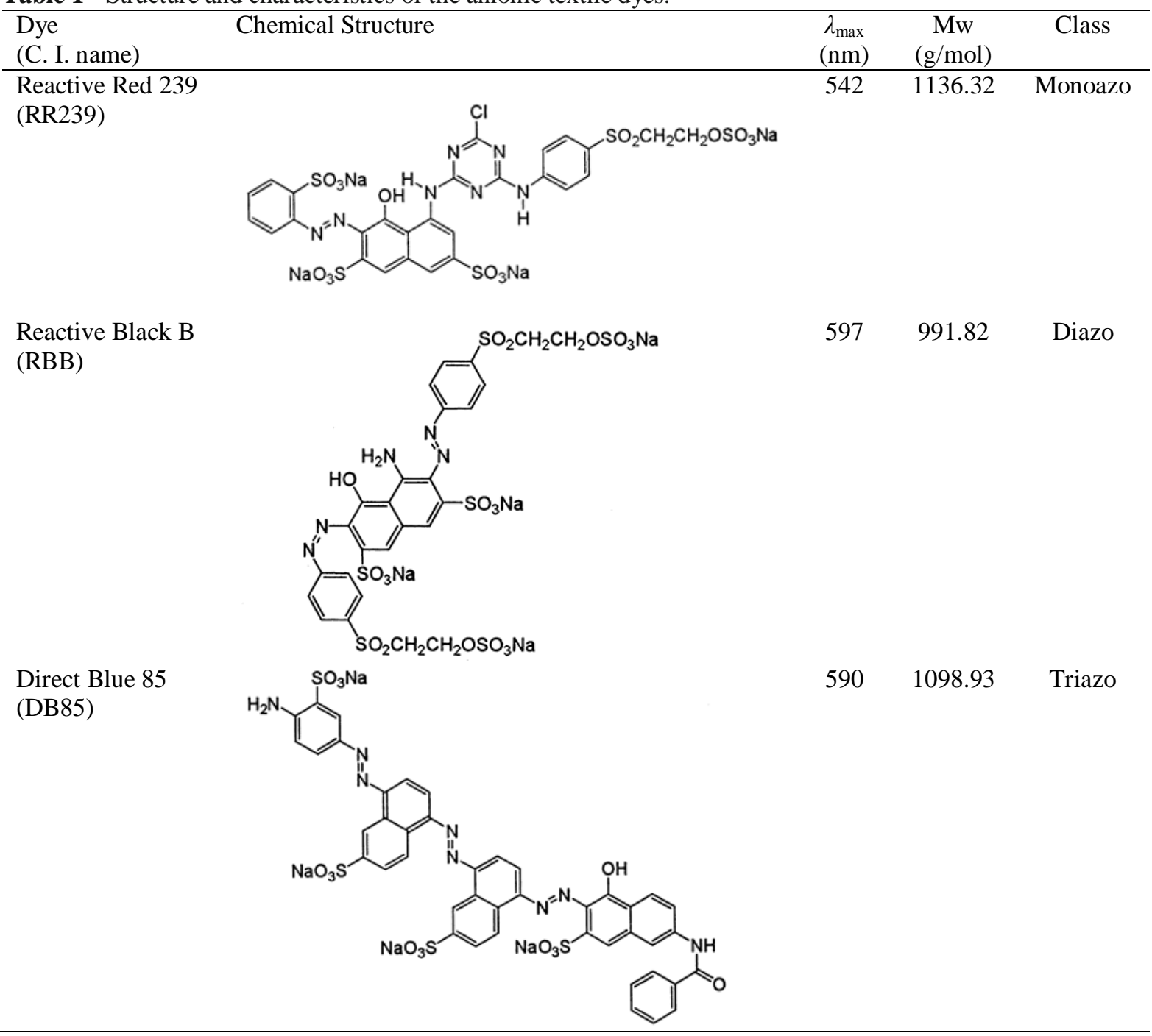

\section{Biosorbent material}

Waste beer yeast slurry (WBYS) purchased from a brewery in Brazil was used as biosorbent material. The WBYS was autoclaved at $121{ }^{\circ} \mathrm{C}$ for $40 \mathrm{~min}$ to kill the yeast cells and ensure that the removal of dyes is due to bioadsorption rather than to biodegradation. In order to estimate the yeast biomass concentration in the waste slurry, it was removed from the suspension by centrifugation $(3600 \mathrm{xg}, 15 \mathrm{~min}$ ), washed several times thoroughly with distilled water and measured by gravimetric method, after drying at $80^{\circ} \mathrm{C}$, to a constant weight. 


\section{Batch biosorption studies}

Experiments were conducted with $150 \mathrm{~mL}$ Erlenmeyer flasks containing $50 \mathrm{~mL}$ of the aqueous solution of dyes. Flasks were agitated on a rotary shaker at $120 \mathrm{rpm}$ and $30{ }^{\circ} \mathrm{C}$. Because adsorption is directly influenced by physicochemical variables, variables such as different $\mathrm{pH}(2,4,6,8$ and 10 , adjusted by the addition of $0.1 \mathrm{M}$ $\mathrm{HCl}$ or $0.1 \mathrm{M} \mathrm{NaOH}$ solutions), initial dye concentration $(100,150,200,250,300$ and $350 \mathrm{mg} / \mathrm{L})$ and biomass dosage $(0.63,1.26,1.89,2.51$ and $3.12 \mathrm{~g}$ biomass/L) were evaluated. At the end of each equilibrium experiment, the biosorbent was removed from the suspension by centrifugation $(3600 \mathrm{x}, 15 \mathrm{~min})$ and the residual dye in the solution was measured quantitatively by a UV-Vis spectrophotometer (Hach DR6000) at $\lambda_{\max }$ of dyes (Table 1). All biosorption experiments were performed in triplicates and the dye removal efficiency, $\mathrm{R}(\%)$, and dye biosorption capacity $\left(q_{e}\right)$ of biomass at the equilibrium were calculated according to the Equations (1) and (2), respectively:

$$
\begin{gathered}
R(\%)=\frac{C_{i}-C_{e}}{C_{i}} \times 100 \\
q_{e}=\frac{\left(C_{i}-C_{e}\right)}{B}
\end{gathered}
$$

where $C_{i}$ and $C_{e}$ are the initial and the equilibrium dye concentrations $(\mathrm{mg} / \mathrm{L})$ and $B$ is the biosorbent concentration in the solution $(\mathrm{g} / \mathrm{L})$.

\section{Kinetic studies}

In this study, the dynamic experimental data were analyzed by the pseudo-first order model (Lagergren, 1898), pseudo-second order (Ho and Mckay, 1998) and the intraparticle diffusion kinetic models (Weber and Morris, 1963).

The linear form of the pseudo-first order equation can be expressed as in Equation (3):

$$
\log \left(q_{e}-q_{t}\right)=\log q_{e}-\frac{K_{1}}{2.303} t
$$

where $q_{e}$ and $q_{t}$ are the amounts of dye adsorbed per biomass $(\mathrm{mg} / \mathrm{g})$ at the equilibrium and at the time $t(\mathrm{~min})$, respectively, and $K_{1}$ is the pseudo-first order rate constant $(1 / \mathrm{min})$. The values of $K_{1}$ and the predicted $q_{\mathrm{e}}$ are determined from the plot of $\log \left(q_{e}-q_{t}\right)$ against $t$.

The linear form of the pseudo-second order model is represented by Equation (4):

$$
\frac{t}{q_{t}}=\frac{1}{K_{2} q_{e}^{2}}+\frac{1}{q_{e}} t
$$

where $q_{e}$ and $q_{t}$ are the amounts of dye adsorbed per biomass $(\mathrm{mg} / \mathrm{g})$ at the equilibrium and at the time $t(\mathrm{~min})$, respectively, and $K_{2}$ is the pseudo-second order rate constant $(\mathrm{g} /(\mathrm{mg} \mathrm{min}))$. By plotting $t / q_{t}$ versus $t$, the models parameters $K_{2}$ and $q_{\mathrm{e}}$ can be determined.

The intraparticle diffusion model allows to identify the diffusion mechanisms and can be represented by Equation (5):

$$
q_{t}=K_{\mathrm{id}} t^{0.5}+C
$$

where $C$ is the intercept and $K_{\text {id }}$ is the intraparticle diffusion rate constant $(\mathrm{mg} /(\mathrm{g}$ $\left.\min ^{0.5}\right)$ ). From the plot of $q t$ against $t^{0.5}$, the values of $K_{\text {id }}$ and $C$ can be obtained. If 
the plot crosses the origin $(C=0)$, the adsorption process is controlled only by intraparticle diffusion.

\section{Isotherm studies}

Langmuir and Freundlich isotherm models were used to describe the equilibrium sorption data (Langmuir, 1918; Freundlich, 1906). The Langmuir isotherm model assumes monolayer coverage of adsorbate over a homogeneous adsorbent surface. The linearized form of the Langmuir is given by Equation (6):

$$
\frac{C_{e}}{q_{e}}=\frac{1}{K_{L} q_{\max }}+\frac{C_{e}}{q_{\max }}
$$

where $q_{e}(\mathrm{mg} / \mathrm{g})$ is the amount of dye adsorbed by the biomass at the equilibrium, $C_{e}$ $(\mathrm{mg} / \mathrm{L})$ is the dye concentration in the solution at the equilibrium, $q_{\max }(\mathrm{mg} / \mathrm{g})$ is the maximum monolayer adsorption capacity, and $K_{L}(\mathrm{~L} / \mathrm{mg})$ is the Langmuir constant related to the affinity of the binding sites and adsorption energy. The plot of $C_{e} / q_{e}$ versus $C_{e}$ is employed to generate the values of $q_{\max }$ and $K_{L}$.

The Freundlich isotherm is an empirical equation employed to describe heterogeneous adsorption surface and is given by Equation (7):

$$
\ln q_{e}=\ln K_{f}+\frac{1}{n} \ln C_{e}
$$

where $K_{f}\left((\mathrm{mg} / \mathrm{g})(\mathrm{mg} / \mathrm{L})^{-1 / \mathrm{n}}\right)$ and $n$ (dimensionless) are Freundlich constant related to the adsorption capacity and adsorption intensity, respectively. $K_{f}$ and $n$ can be evaluated by plotting $\ln q_{e}$ and $\ln C_{e}$.

\section{RESULTS AND DISCUSSION}

\section{Effect of pH}

The initial $\mathrm{pH}$ of the solution significantly influences the dye biosorption process because it affects the adsorbate solubility and the ionizing functional groups of the cell walls (Aksu and Dönmez, 2003; Khataee et al., 2013). Figure 1 illustrates the effect of different initial $\mathrm{pH}$ on the removal of three dyes at a dye concentration of $100 \mathrm{mg} / \mathrm{L}$ for $60 \mathrm{~min}, 30{ }^{\circ} \mathrm{C}$ and $3.12 \mathrm{~g}$ biomass/L. At $\mathrm{pH} \mathrm{2}$, it was observed the highest values of biosorption of dyes: 96\% (DB85), 99\% (RR239) and 100\% (RBB). As the $\mathrm{pH}$ of the aqueous solution increased, the removal of the three dyes by the biomass decreased. This effect is related to the protonation of functional groups on the surface of the biomass under acidic conditions, resulting in net positive charge on the biomass ( $\mathrm{Wu}$ et al. 2011). The electrostatic interactions between the positively charged biosorbent and the negatively charged dye anions lead to dye removal from the solution. As the $\mathrm{pH}$ of the medium increases, the number of negatively charged sites increases on the biomass surface, which does not favor the adsorption of dye anions due to the electrostatic repulsion (Iscen et al. 2007; Akar et al. 2009). Similar $\mathrm{pH}$ trends were reported by other researchers for yeast biomass (Aksu and Dönmez, 2003; Wu et al., 2011; Wang and Guo, 2011). 


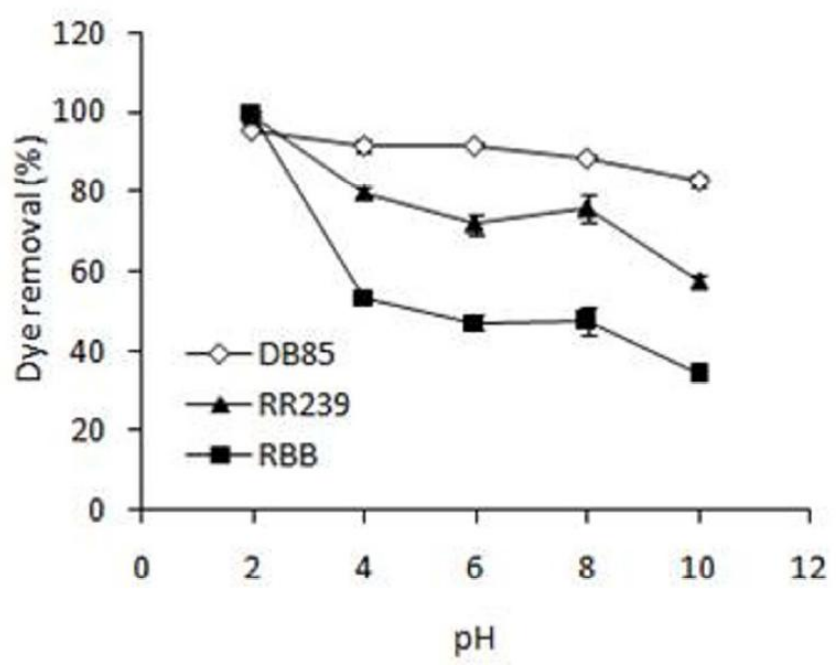

Fig. 1. Effect of $\mathrm{pH}$ on the dye removal efficiency of WBYS (biosorbent dosage $=3.12 \mathrm{~g}$ biomass/L), dye concentration $=100 \mathrm{mg} / \mathrm{L}$, contact time $=60 \mathrm{~min}$, temperature $\left.=30^{\circ} \mathrm{C}\right)$.

\section{Effect of biosorbent dosage}

Figure 2 shows the effect of biosorbent dosage $(0.63,1.26,1.89,2.51$ and $3.12 \mathrm{~g} / \mathrm{L})$ on the biosorption of dyes. As can be seen, the percentage of removal increased when the biomass dosage improved. The biosorption capacity, however, decreased from 117.7 to $30.5 \mathrm{mg} / \mathrm{g}$ for DB85, from 119.7 to $29.4 \mathrm{mg} / \mathrm{g}$ for RR239 and from 130.6 to $29.3 \mathrm{~g} / \mathrm{L}$ for RBB when the biomass dosage increased from 0.63 to 3.12 $\mathrm{g} / \mathrm{L}$. The decrease in the biosorption capacity at higher WBYS dosage can be attributed to the adsorption sites that remained unsaturated during the adsorption reaction, whereas the number of sites available for adsorption is increased by increasing the biosorbent dosage (Zou et al., 2006). Another reason may be due the interaction of particles such as the aggregation, leading to a decline in the total biosorbent surface area. This fact causes a decrease in the amount of dye biosorbed per unit of weight of biomass (Shukla et al., 2002; Crini and Badot, 2008). Whereas the greatest biosorption capacity was observed at $0.63 \mathrm{~g} / \mathrm{L}$, this biosorbent dosage was used in subsequent studies.

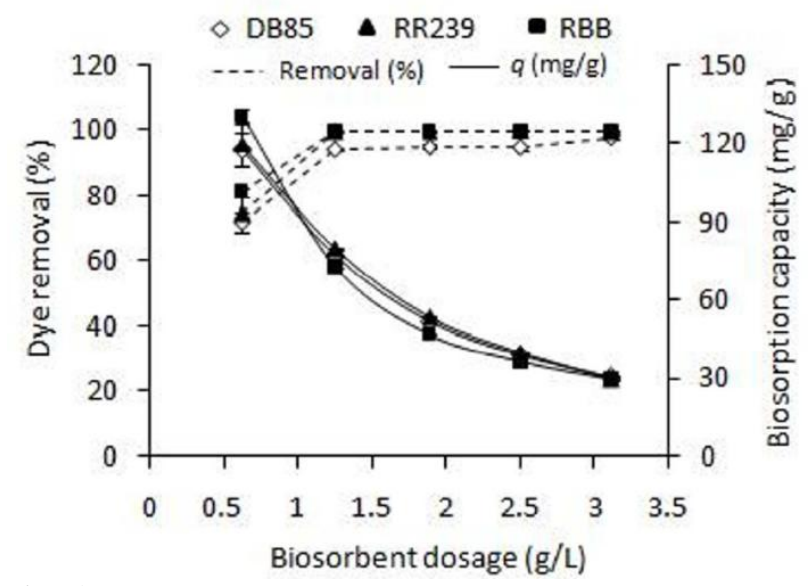

Fig. 2. Effect of biosorbent dosage on the dye removal efficiency of WBYS (dye concentration $=100 \mathrm{mg} / \mathrm{L}$, contact time $=60 \mathrm{~min}, \mathrm{pH}=2$, temperature $=30^{\circ} \mathrm{C}$ ).

\section{Effect of contact time}

Contact time is one important parameter for the successful deployment of biosorbents for practical application. The ideal biosorption materials should be 
capable of quickly adsorbing high concentrations of dyes from the wastewater and establishing the equilibrium (Iscen et al., 2007, Khataee et al., 2013). The influence of the contact time on the biosorption capacity of the WBYS for three dyes can be seen in Figure 3. Results showed that a rapid biosorption of dyes occurred at $5 \mathrm{~min}$ and reached 59\% (DB85), 65\% (RR239) and 76\% (RBB), respectively. After the first $5 \mathrm{~min}$, the biosorption of dyes were gradually slowed down until the equilibrium, which was achieved at $30 \mathrm{~min}$ for RR239 and RBB and at $60 \mathrm{~min}$ for DB85. The rapid biosorption of the three dyes by the WBYS in the first 5 min can be attributed to the high availability of active sites on the cell surface. As these functional groups are gradually occupied, the biosorption became less efficient.

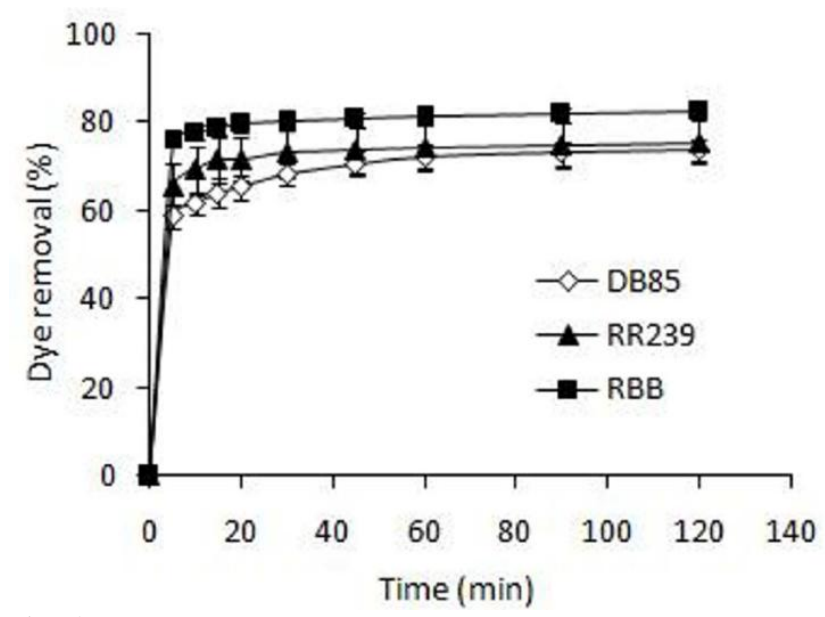

Fig. 3. Effect of contact time on the dye removal efficiency of the WBYS (biosorbent dosage $=0.63 \mathrm{~g}$ biomass $/ \mathrm{L}$ ), dye concentration $=100 \mathrm{mg} / \mathrm{L}$, contact time $=120 \mathrm{~min}$, temperature $=30^{\circ} \mathrm{C}$ ).

\section{Effect of initial concentration of dye}

The initial concentration of dye provides an important driving force to overcome all mass transfer resistances of the dye between the aqueous and the solid phases (Aksu and Dönmez, 2003). In this study, dye removal capacity of the WYBS was investigated using solutions of dyes that ranged from 50 to $350 \mathrm{mg} / \mathrm{L}$, with pH 2 and temperature of $30^{\circ} \mathrm{C}$. The dye removal efficiency and the biosorption capacity of the WBYS are given in Figure 4. Despite the decrease in dye removal efficiency with the increase in the initial dye concentration, the biosorption capacity was increased. The biosorption capacity reached maximum values of 139.0 and $160.8 \mathrm{mg} / \mathrm{g}$ for DB85 and RR239, respectively at $250 \mathrm{mg} / \mathrm{L}$ and $158.7 \mathrm{mg} / \mathrm{g}$ for RBB at $300 \mathrm{mg} / \mathrm{L}$. Dye removal efficiency was higher at lower initial dye concentration because all dye concentration may interact with the binding sites on the cell surface while at higher dye concentration, the binding sites on the biomass surface are saturated and no further biosorption occurs. A decrease in the biosorption capacity observed at RR239 concentration above $250 \mathrm{mg} / \mathrm{L}$ can be related to the repulsive forces between the dye molecules at the adjacent sites on the cell surface, which leads to a removal of some dye molecules from the surface (Iscen et al., 2007). 


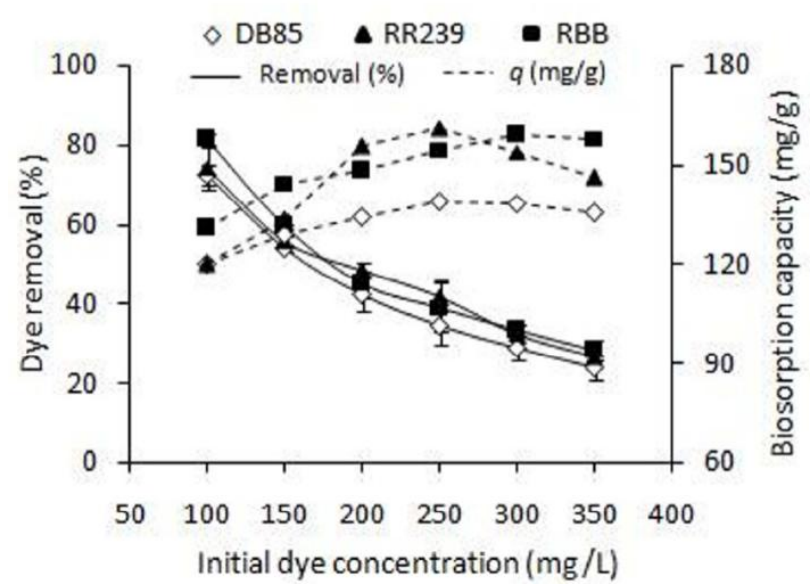

Fig. 4. Effect of initial dye concentration on the dye removal efficiency of the WBYS (biosorbent dosage $=0.63 \mathrm{~g}$ biomass $/ \mathrm{L}$ ), dye concentration $=100 \mathrm{mg} / \mathrm{L}$, contact time $=60 \mathrm{~min}$, temperature $=30^{\circ} \mathrm{C}$ ).

\section{Biosorption kinetics}

Kinetics studies are important for designing and optimizing the biosorption system. In this study, kinetic studies of dyes removal were conducted using $150 \mathrm{~mL}$ Erlenmeyer flasks with $50 \mathrm{~mL}$ of dye aqueous solution $(100 \mathrm{mg} / \mathrm{L}), 0.63 \mathrm{~g}$ biomass/L, at various contact times $(5-60 \mathrm{~min})$, at $30^{\circ} \mathrm{C}$ and $120 \mathrm{rpm}$.

The parameters calculated for the pseudo-first order, pseudo-second order and intraparticle diffusion kinetic models are listed in Table 2. Although the pseudo-first order model has generated a good fit $\left(R^{2}>0.96\right.$ for all dyes, Fig. 5), the experimental $q_{e}$ values $(119.7,130.6,120.1 \mathrm{mg} / \mathrm{g}$ for RR239, RBB, and DB85, respectively) did not agree with those that were calculated $\left(q_{1}\right)$ (Table 2). On the other hand, the pseudo-second order model generated the best fit $\left(R^{2}>0.99\right.$ for all dyes, Fig. 6) and the biosorption capacities $\left(q_{2}\right)$ estimated by the models were also close to those acquired by the experiments. In the case of intraparticle diffusion model, the correlation coefficients were between 0.83 and 0.98 and the $C$ values were different from zero indicating that the intraparticle diffusion is not the only rate-limiting step (Fig. 7). These results suggest that the biosorption of dye by the WBYS is complex and may involve more than one mechanism. The biosorption process was probably controlled by a chemisorption reaction, but a thermodynamic evaluation is necessary to confirmation this process. The chemisorption reaction involves the sharing or exchanging of electrons between biomass and dye until the surface active sites were fully occupied. Once the activated sites of the external surface reached saturation, the dye molecule diffused into the biomass network was adsorbed onto the active sites in the interior of the biosorbent particle (Malik, 2004; WU et al., 2011). 
Biosorption of anionic textile dyes by brewer's yeast

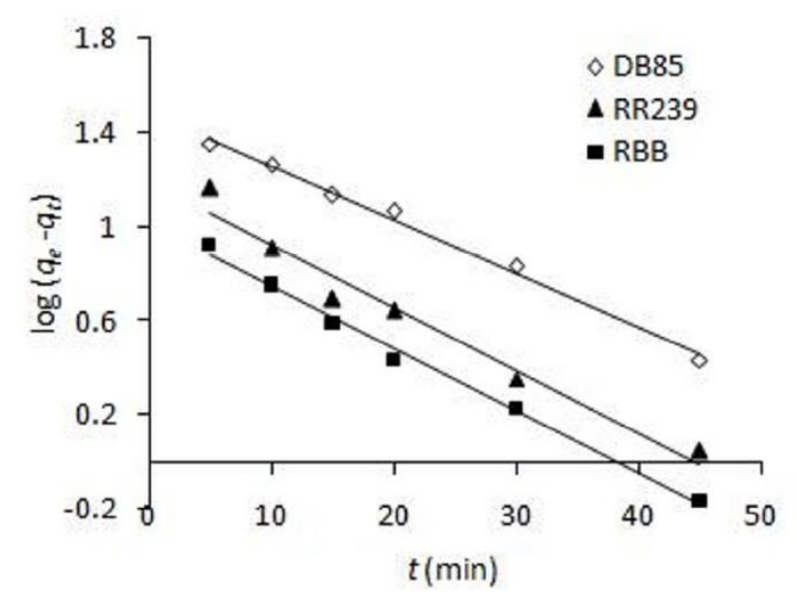

Fig. 5 Pseudo first-order kinetic plots for the anionic dyes removal efficiency of the WBYS.

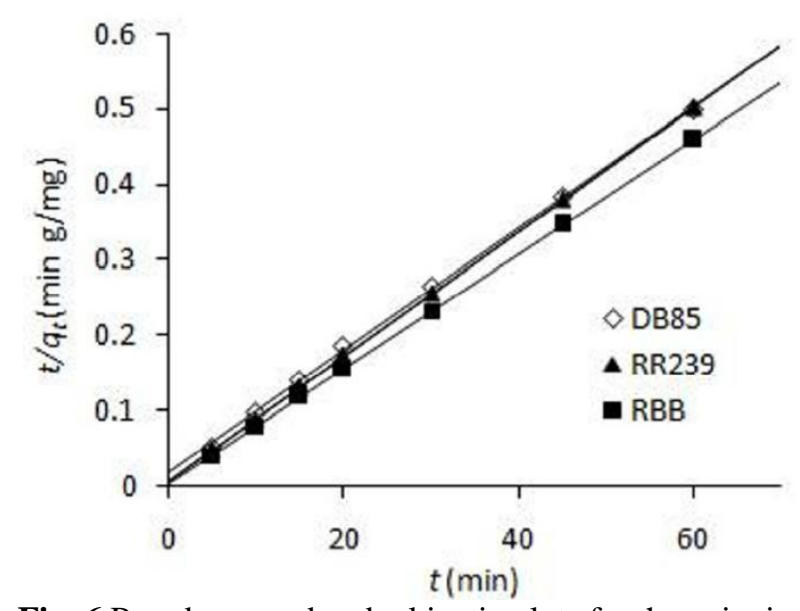

Fig. 6 Pseudo second-order kinetic plots for the anionic dyes removal efficiency of the WBYS.

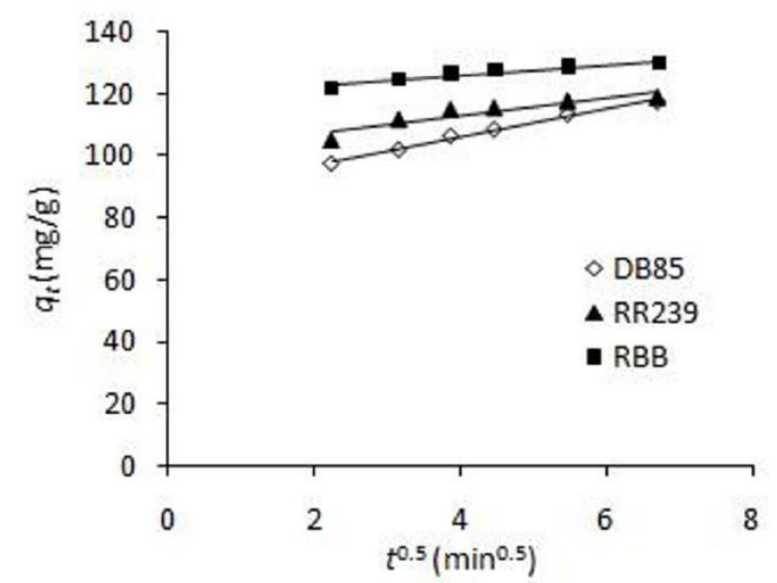

Fig. 7 Intraparticle diffusion kinetic plots for the anionic dyes removal efficiency of the WBYS. 
Table 2 - Kinetic parameters estimated by the pseudo first-order, pseudo second-order and intraparticle diffusion models for the RR239, RBB and DB85 biosorptions on the WBYS.

\begin{tabular}{|c|c|c|c|c|c|c|c|c|c|}
\hline \multirow[t]{2}{*}{ Model } & \multicolumn{3}{|c|}{ Pseudo-first order } & \multicolumn{3}{|c|}{ Pseudo-second order } & \multicolumn{3}{|c|}{ Intraparticle diffusion } \\
\hline & $\begin{array}{l}K_{1} \\
(1 / \mathrm{min})\end{array}$ & $\begin{array}{l}q_{1} \\
(\mathrm{mg} / \mathrm{g})\end{array}$ & $R^{2}$ & $\begin{array}{l}K_{2} \\
(\mathrm{~g} /(\mathrm{mg} \\
\mathrm{min}))\end{array}$ & $\begin{array}{l}q_{2} \\
(\mathrm{mg} / \mathrm{g})\end{array}$ & $R^{2}$ & $\begin{array}{l}K_{\text {id }} \\
\left(\mathrm{mg} /\left(\mathrm{g} \mathrm{min}^{0.5}\right)\right)\end{array}$ & $\begin{array}{l}C \\
(\mathrm{mg} / \mathrm{g})\end{array}$ & $R^{2}$ \\
\hline RR239 & 0.0615 & 15.62 & 0.968 & 0.0093 & 121.23 & 1.000 & 2.3411 & 103.38 & 0.830 \\
\hline $\mathrm{RBB}$ & 0.0612 & 10.34 & 0.993 & 0.0145 & 131.53 & 1.000 & 1.4410 & 120.35 & 0.905 \\
\hline DB85 & 0.0527 & 31.05 & 0.995 & 0.0037 & 123.49 & 0.999 & 4.1651 & 89.26 & 0.984 \\
\hline
\end{tabular}

\section{Biosorption isotherm}

The equilibrium biosorption isotherm is prerequisite to understand how adsorbates interact with adsorbents and how they could be used for design purpose. In this study, $q_{e}$ as a function of the dye concentration at the equilibrium plot was fit with the Langmuir and Freundlich isotherm equations. Table 3 lists the Langmuir and Freundlich adsorption isotherms constant with the correlation coefficients. It could be seen that the Langmuir isotherm fits better $\left(R^{2}>0.99\right.$ for all dyes, Fig. 8$)$ than the Freundlich isotherm (Fig. 9). These results revealed that the biosorption process was based on the monolayer adsorption. The maximum biosorption capacities $\left(q_{\max }\right)$ calculated by the Langmuir model were $152.93,162.73$ and $139.16 \mathrm{mg} / \mathrm{g}$ for RR239, RBB and DB85, respectively.

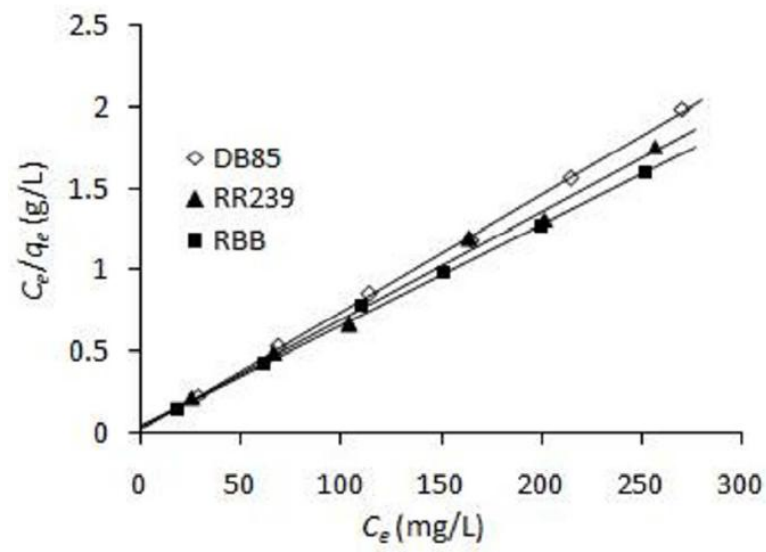

Fig. 8 Langmuir isotherms for the biosorption of RRB239, RBB and DB85 on the WBYS.

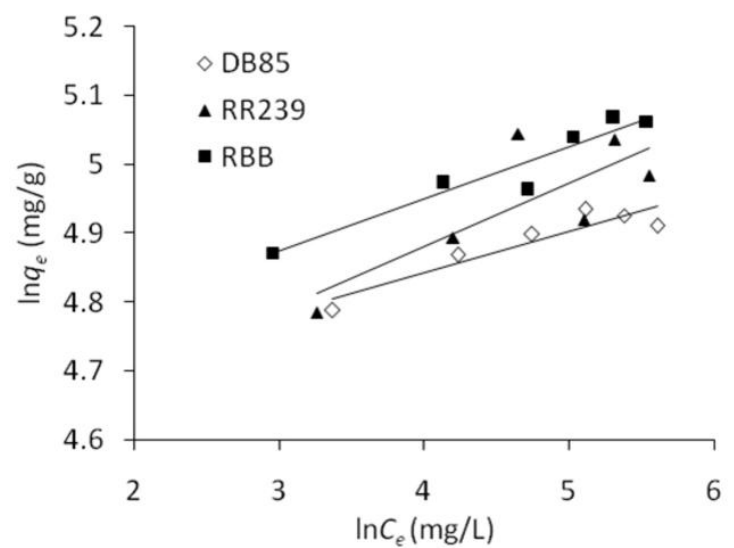

Fig. 9 Freundlich isotherms for the biosorption of RRB239, RBB and DB85 on the WBYS. 
The essential features of the Langmuir isotherm can be expressed in terms of the dimensionless constant separation factor or equilibrium parameter, $R_{\mathrm{L}}$ (Mckay et al., 1982):

$$
R_{\mathrm{L}}=\frac{1}{1+K_{\mathrm{L}} C_{i}}
$$

where $C_{i}$ is the highest initial dye concentration $(\mathrm{mg} / \mathrm{L}) . R_{\mathrm{L}}$ can be used for the interpretation of the adsorption process as follows: irreversible $\left(R_{\mathrm{L}}=0\right)$, favorable $(0$ $\left.<R_{\mathrm{L}}<1\right)$, linear $\left(R_{\mathrm{L}}=1\right)$ or unfavorable $\left(R_{\mathrm{L}}>1\right)$. The $R_{\mathrm{L}}$ values found were 0.011 , 0.009 and 0.023 for DB85, RR239 and RRB respectively, indicating that the sorption process is favorable.

Table 3 - Biosorption isotherm constants for RRB239, RBB and DB85 biosorptions on the WBYS.

\begin{tabular}{|c|c|c|c|c|c|c|}
\hline \multirow[t]{2}{*}{ Model } & \multicolumn{3}{|c|}{ Langmuir constant } & \multicolumn{3}{|c|}{ Freundlich constant } \\
\hline & $\begin{array}{l}q_{\max } \\
(\mathrm{mg} / \mathrm{g})\end{array}$ & $\begin{array}{l}K_{\mathrm{L}} \\
(\mathrm{L} / \mathrm{mg})\end{array}$ & $R^{2}$ & $\begin{array}{l}K_{\mathrm{F}} \\
(\mathrm{mg} / \mathrm{g})(\mathrm{mg} / \mathrm{L})^{-1 / \mathrm{n}}\end{array}$ & $n$ & $R^{2}$ \\
\hline RR239 & 152.93 & 0.310 & 0.992 & 86.59 & 9.12 & 0.668 \\
\hline RBB & 162.73 & 0.123 & 0.998 & 104.14 & 13.14 & 0.918 \\
\hline DB85 & 139.16 & 0.265 & 0.999 & 99.57 & 16.50 & 0.865 \\
\hline
\end{tabular}

\section{CONCLUSION}

The present study revealed that waste beer yeast slurry can be used as biosorbent to remove three anionic textile dyes (RR239, RBB, DB85) from aqueous solution. The biosorption process of dyes proved to be dependent on the $\mathrm{pH}$ of the solution, on the contact time, biosorbent dosage and initial concentration of dyes. Optimum $\mathrm{pH}$ and biosorbent dosage were determined as being 2.0 and $0.63 \mathrm{~g} / \mathrm{L}$, respectively. Batch studies showed that the kinetics were well described by the pseudo-second-order model, and the equilibrium was well described by the Langmuir model. In conclusion, waste beer yeast slurry may be an economic, effective and eco-friendly option for the removal of anionic dyes from aqueous media.

\section{ACKNOWLEDGMENTS}

This work was supported by CNPq under Grant 486168/2013-1

\section{REFERENCES}

1. Akar ST, Özcan AS, Akar T, Özcan A, Kaynak Z. Biosorption of a reactive textile dye from aqueous solutions utilizing an agro-waste. Desalination. 2009; 249(2): 757-761.

2. Aksu Z, Dönmez G. A comparative study on the biosorption characteristics of some yeasts for Remazol Blue reactive dye. Chemosphere. 2003; 50(8): 1075-1083.

3. Al-Amrani WA, Lim PE, Seng CE, Ngah WSW. Factors affecting bio-decolorization of azo dyes and COD removal in anoxic-aerobic REACT operated sequencing batch reactor. J. Taiwan Inst Chem Eng. 2014; 45(2): 609-616.

4. Banat IM, Nigam P, Singh D, Marchant R. Microbial decolorization of textile-dyecontaining effluents : A review. Bioresour Technol. 1997; 58(3):, 217-227.

5. Chen KC, Wu JY, Liou DJ, Hwang SCJ. Decolorization of the textile dyes by newly isolated bacterial strains. J Biotechnol. 2003; 101(1): 57-68.

6. Chevalier, LR, Yesuf, JN, Knowles LS. Evaluation of textile dye sorption on GAC produced from almond shells based on optimized isotherm models. Environ Eng Sci. 2007; 24(4): 563-579. 
7. Crini C, Badot PM. Application of chitosan, a natural aminopolysaccharide, for dye removal from aqueous solutions by adsorption processes using batch studies: A review of recent literature. Prog Polym Sci. 2008; 33(4): 399-447.

8. Daneshvar E, Kousha M, Sohrabi MS, Khataee A, Converti A. Biosorption of three acid dyes by the brown macroalga Stoechospermum marginatum: Isotherm, kinetic and thermodynamic studies. Chem Eng J. 2012; 195-196: 297-306.

9. Deniz F, Karaman S. Removal of an azo-metal complex textile dye from colored aqueous solutions using an agro-residue. Microchem J. 2011; 99(2): 296-302.

10. Ferreira BCS, Teodoro FS, Mageste AB, Gil LF, de Freitas RP, Gurgel LVA. Application of a new carboxylate-functionalized sugarcane bagasse for adsorptive removal of crystal violet from aqueous solution: Kinetic, equilibrium and thermodynamic studies. Ind Crops Prod. 2015; 65: 521-534.

11. Freundlich H. Over the adsorption in the solution. J Phys Chem. 1906; 57: 385-470.

12. Gill PK, Arora DS, Chander M. Biodecolourization of azo and triphenylmethane dyes by Dichomitus squalens and Phlebia spp. J Ind Microbiol Biotechnol. 2002; 28: 201-203.

13. Han MH, Yun YS. Mechanistic understanding and performance enhancement of biosorption of reactive dyestuffs by the waste biomass generated from amino acid fermentation process. Biochem Eng J. 2007; 36(1): 2-7.

14. Han R, Li H, Li Y, Zhang J, Xiao H, Shi J. Biosorption of copper and lead ions by waste beer yeast. J Hazard Mater. 2006; 137(3): 1569-1576.

15. Ho YS, Mckay G. Kinetic models for the sorption of dye from aqueous solution by wood. Trans Chem Eng. 1998; 76(2): 183-191.

16. Iscen CF, Kiran I, Ilhan S. Biosorption of Reactive Black 5 dye by Penicillium restrictum: The kinetic study. J Hazard Mater. 2007; 143(1-2): 335-340.

17. Juang LC, Lee CK, Wang CC, Hung SH, Lyu MD. Adsorptive removal of Acid Red 1 from aqueous solution with surfactant modified titanate nanotubes. Environ Eng Sci. 2008; 25(4): 519-528.

18. Kalaiarasi K, Lavanya A, Amsamani S, Bagyalakshmi G. Decolourization of textile dye effluent by non-viable biomass of Aspergillus fumigates. Braz Arch Biol Technol. 2012; 55(3): 471-476

19. Khataee AR, Vafaei F, Jannatkhah M. Biosorption of three textile dyes from contaminated water by filamentous green algal Spirogyra sp.: Kinetic, isotherm and thermodynamic studies. Int Biodeterior Biodegrad. 2013; 83, 33-40.

20. Kim TY, Park SK, Cho SY, Kim HB, Kang Y, Kim SD, Kim SJ. Adsorption of heavy metals by brewery biomass. Korean J Chem Eng. 2005; 22(1): 91-98.

21. Kumari K, Abraham TE. Biosorption of anionic textile dyes by nonviable biomass of fungi and yeast. Bioresour Technol 2007; 98(9): 1704-1710.

22. Lagergren S. Zur theorie der sogenannten adsorption gelster stoffe. $K$ Sven Vetenskapsakad Handl 1898; 24: 1-39.

23. Langmuir I. The adsorption of gases on plane surfaces of glass, mica and platinum. J Am Chem Soc. 1918; 40(9): 1361-1403.

24. Machado MD, Soares EV, Soares HMVM. Removal of heavy metals using a brewer's yeast strain of Saccharomyces cerevisiae: Chemical speciation as a tool in the prediction and improving of treatment efficiency of real electroplating effluents. J Hazard Mater. 2010; 180(1-3): 347-353.

25. Mckay G, Blair HS, Gardner JK. Adsorption of dyes on chitin. 1. Equilibrium studies. $J$ Appl Polymer Sci. 1982; 27: 3043-3057.

26. Malik PK. Dye removal from wastewater using activated carbon developed from sawdust: Adsorption equilibrium and kinetics. J Hazard Mater. 2004; 113(1-3): 81-88.

27. Parvathi K, Nagendran R. Functional groups on waste beer yeast involved in chromium biosorption from electroplating effluent. World J Microbiol Biotechnol. 2008; 24: 28652870.

28. Ramírez-Paredes FI, Manzano-Muñoz T, Garcia-Prieto JC, Zhadan GG, Shnyrov VL, Kennedy JF, et al. Biosorption of heavy metals from acid mine drainage onto biopolymers (chitin and $\alpha(1,3) \beta$-D-glucan) from industrial biowaste exhausted brewer's yeasts (Saccharomyces cerevisiae L.). Biotechnol Bioprocess Eng. 2011; 16, 1262-1272.

29. Raymundo AS, Zanarotto R, Belisário M, Pereira MG, Ribeiro JN, Ribeiro AVFN. Evaluation of sugar-cane bagasse as bioadsorbent in the textile wastewater treatment 
Biosorption of anionic textile dyes by brewer's yeast

contaminated with carcinogenic Congo Red dye. Braz Arch Biol Technol. 2010; 53(4): 931938.

30. Riordan C, Bustard M, Putt R, McHale AP. Removal of uranium from solution using residual brewery yeast: Combined biosorption and precipitation. Biotechnol Lett. 1997; 19(4): 385-387.

31. Robinson T, Chandran B, Nigam P. Removal of dyes from a synthetic textile dye effluent by biosorption on apple pomace and wheat straw. Water Res. 2002; 36(11): 2824-2830.

32. Saratale RG, Saratale GD, Chang JS, Govindwar SP. Bacterial decolorization and degradation of azo dyes: A review. J Taiwan Inst Chem Eng. 2011; 42(1): 138-157.

33. Subramaniam R, Ponnusamy SK. Novel adsorbent from agricultural waste (cashew NUT shell) for methylene blue dye removal: Optimization by response surface methodology. Water Resour Ind. 2015; 11, 64-70.

34. Shukla A, Zhang YH, Dubey P, Margrave JL, Shukla SS. The role of sawdust in the removal of unwanted materials from water. J Hazard Mater. 2002; 95(1-2): 137-152.

35. Tunç Ö, Tanaci H, Aksu Z. Potential use of cotton plant wastes for the removal of Remazol Black B reactive dye. J Hazard Mater. 2009; 163(1): 187-198.

36. Verma AK, Raghukumar C, Parvatkar RR, Naik CG. A Rapid Two-Step Bioremediation of the anthraquinone aye, reactive Blue 4 by a marine-derived fungus. Water, Air, Soil Pollut. 2012; 223: 3499-3509.

37. Yu J, Zhu J, Feng L, Chi R. Simultaneous removal of cationic and anionic dyes by the mixed sorbent of magnetic and non-magnetic modified sugarcane bagasse. J Colloid Interface Sci. 2015; 451: 153-160.

38. Wang B, Guo X. Reuse of waste beer yeast sludge for biosorptive decolorization of reactive blue 49 from aqueous solution. World J Microbiol Biotechnol. 2011; 27(6): 12971302 .

39. Weber MJ, Morris JC. Kinetic of adsorption on carbon from solution. J Sanit Eng. Div. ASCE. 1963; 89: 31-60.

40. Wu Y, Hu Y, Xie Z, Feng S, Li B, Mi X. Characterization of biosorption process of acid orange 7 on waste brewery's yeast. Appl Biochem Biotechnol. 2011; 163(7): 882-894.

41. Zou W, Han R, Chen Z, Shi J, Hongmin L. Characterization and properties of manganese oxide coated zeolite as adsorbent for removal of copper (II) and lead (II) ions from solution. J Chem Eng. 2006; 51(2): 534-541. 